\title{
Universiteit
}

Leiden

The Netherlands

\section{The cross-linguistic syntax of sluicing: evidence from Hungarian relatives}

Lipták, A.K.; Van Craenenbroeck, J.

\section{Citation}

Lipták, A. K., \& Van Craenenbroeck, J. (2006). The cross-linguistic syntax of sluicing: evidence from Hungarian relatives. Syntax, 9(3), 248-274. doi:10.1111/j.1467-9612.2006.00091.x

Version:

Publisher's Version

License:

Licensed under Article 25fa Copyright Act/Law (Amendment Taverne)

Downloaded from: $\quad$ https://hdl.handle.net/1887/3193493

Note: To cite this publication please use the final published version (if applicable). 


\title{
THE CROSSLINGUISTIC SYNTAX OF SLUICING: EVIDENCE FROM HUNGARIAN RELATIVES
}

\author{
Jeroen van Craenenbroeck and Anikó Lipták
}

\begin{abstract}
This paper deals with an elliptical construction in Hungarian that to our knowledge has not received any attention in the theoretical literature so far. It involves the deletion of a relative clause with the exclusion of the relative pronoun and one more remaining constituent. We show that this construction should be analyzed as an instance of sluicing. The theoretical approach we provide for these sentences is an adapted version of Merchant's (2001) implementation of sluicing in terms of an [E]feature that is responsible for the deletion process. Our extension of this proposal involves the modification of the syntactic subcontent of this [E]-feature. We show that languages where question words are found in the operator domain of the left periphery use a version of the [E]-feature that attaches to heads whose specifier is occupied by an operator. This predicts that sluicing not only occurs with $w h$-remnants but more widely with operator remnants as well. With this proposal we lay the foundation for a crosslinguistic taxonomy of sluicing constructions, and open new avenues towards explaining root/embedded asymmetries in some as yet ill-understood elliptical phenomena in English.
\end{abstract}

\section{Introduction}

The focus of this paper is a Hungarian elliptical construction in which the bulk of a relative clause is elided. As a result of this deletion process, everything but the relative pronoun and one more constituent is missing in the relative clause. We refer to this construction as relative deletion (henceforth RD). A representative example is given in (1). ${ }^{1}$

(1) Kornél AZT A LÁNYT hívta meg,
Kornél that-ACC the girl-ACC invited PV
akit ZOLTÁN $[e]$.
REL-who-ACC Zoltán
'The girl who Kornél invited was the one who
Zoltán did.'

* We hereby acknowledge the support of the NWO-OTKA (Netherlands Organization for Scientific Research-Hungarian Scientific Research Fund) N37276 "The Syntax, Semantics, and Phonology of the Left Periphery" grant. We would also like to thank Marcel den Dikken, István Kenesei, Jason Merchant, two anonymous Syntax-reviewers, and the audiences of SICOGG 7 (Seoul, August 2005), the SOS workshop (Tilburg, October 2005), and the Edges in Syntax workshop (Nicosia, May 2006) for valuable comments. All errors and shortcomings are ours.

${ }^{1}$ The notation and abbreviations in the glosses are as follows: ACC $=$ accusative case; $\mathrm{DAT}=$ dative case; $\mathrm{CL}=$ clitic; $\mathrm{COND}=$ conditional marker; $\mathrm{HAB}=$ habitual marker (auxiliary); $\mathrm{PV}=$ preverb(al element $) ; \mathrm{REL}=$ relative morpheme; POSS $=$ possessive morpheme. Nominative case is not glossed and person/number features and tense are glossed only when relevant. Small capitals indicate focus, and $[e]$ signals that this is an elliptical construction. 
The nonelliptical version of this example is also well formed:

Kornél AZT A LÁNYT hívta meg,
Kornél that-ACC the girl-ACC invited PV
akit ZOLTÁN hívott meg.
REL-who-ACC Zoltán invited PV
'The girl who Kornél invited was the one who Zoltán did.'

Our goal in this paper is to provide an analysis for the construction in (1), in which only the relative pronoun and one more constituent survive the deletion process. The paper is organized as follows. In section 2 we introduce and illustrate RD somewhat further, as well as point out some restrictions on it. In section 3 we try to identify the size of the elided constituent, thus arriving at the hypothesis that RD is an instance of sluicing. Section 4 lays the theoretical groundwork for the analysis. We start out from Merchant's (2001) implementation of sluicing in terms of the [E]-feature. We then modify the syntactic content of that feature by relativizing it across language types. As such, our account can be seen as a first step toward a crosslinguistic taxonomy of sluicing constructions. Section 5 contains the actual analysis of relative deletion in Hungarian, and section 6 discusses some of the predictions our account makes, as well as a possible extension of our proposal. Section 7 sums up and concludes.

\section{Hungarian Relative Deletion: The Basic Data}

RD can leave behind remnants of any category and any grammatical function. The following examples illustrate nonsubject remnants:

(3) $\mathrm{Az}$ A FIÚ hívta meg Esztert, aki KATIT $[e]$. that the boy invited PV Eszter-ACC REL-who Kati-ACC 'The boy who invited Eszter was the one who invited Kati.'

(4) Péternek AZT A FOTÓT mutattam meg, Péter-DAT that-ACC the photo-ACC showed PV amit ANNÁNAK [e].

REL-what-ACC Anna-DAT

'The photo I showed to Péter was the one that I showed to Anna.'

(5) Az A FIÚ utazott el Marival, aki that the boy traveled PV Mari-WITH REL-who Olgával $[e]$.

Olga-WITH

'The boy who went traveling with Mari is the one who went traveling with Olga.' 
As is clear from the translations of these sentences, as well as the syntax of the matrix clause, in all these examples we find the head of the relative clause (azt a lányt 'that girl' in (1), az a fiú 'that boy' in (3) and (5), and azt a fotót 'that photo' in (4)) in the (contrastive) focus position in the matrix clause. Syntactically this is indicated by verb-preverb inversion: Hungarian contrastive focus is always adjacent to the verbal head, forcing the preverb to follow that verbal head (Brody 1995). ${ }^{2}$

$\mathrm{RD}$ can also occur in sentences without focus on the relative head, however. Unlike the examples with focus above, which are accepted by everyone, focusless examples show some variation among speakers. A small percentage of more liberal speakers find the focusless versions just as good as the focused ones. The large majority of speakers, on the other hand, finds focusless examples degraded to some (sometimes varying) degree, with judgments ranging from ? to ?*. These speakers prefer to spell out is 'also, even' after the remnant in the relative clause to make the sentence fully grammatical. The addition of such an item is perfectly fine for every native speaker, also for the liberal ones who do not require this item. The importance of is 'also, even' is an issue we return to in section $5 .{ }^{3}$

(6) Kornél meghívta azt a lányt, akit

Kornél PV-invited that-ACC the girl-ACC REL-who-ACC

Zoltán ${ }^{\%}$ (is) $[e]$.

Zoltán also

'Kornél invited the girl who Zoltán did (too).'

(7) $\mathrm{Az}$ a fiú meghívta Esztert, aki

that the boy PV-invited Eszter-ACC REL-who

Katit $\%$ (is) $[e]$.

Kati-ACC also

'The boy who invited Eszter was the one who invited Kati (too).'

(8) Péternek megmutattam azt a fotót, Péter-DAT PV-showed that-ACC the photo-ACC amit Annának $\%$ (is) $[e]$.

REL-what-ACC Anna-DAT also

'The photo I showed to Péter was the one that I showed to Anna (too).'

\footnotetext{
${ }^{2}$ As for the focus on the remnant to the right of the relative pronoun, see section 5 .

${ }^{3}$ It is interesting to note that a similar effect has been observed by Vanden Wyngaerd and Zwart (1991) for English VP-ellipsis in ACD-contexts (see (i)). We leave the analysis of such examples as a topic for further research.
}

(i) Philby suspected Angleton, who Dulles did $[e] *($ ?as well). 
RD can occur in short replies to wh-questions. (Structurally, since an answer to a wh-question always supplies the questioned constituent as syntactic focus, these examples are like (1) and (3)-(5), in that they involve focus on the head of the relative clause.)

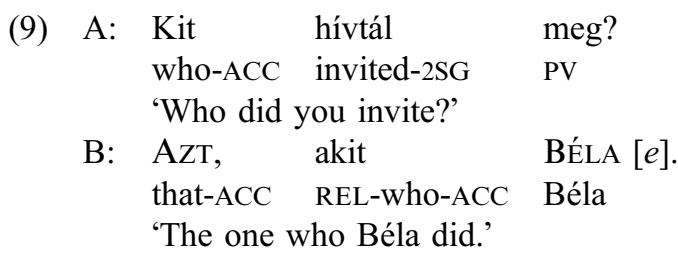

The examples we have discussed so far might give the impression that Hungarian RD is restricted to ACD contexts. Specifically, in (1) and (3)-(5) the deletion process takes place in a relative clause that is itself contained inside the antecedent of the deleted structure. Moreover, on the assumption that in B's reply in (9) ellipsis of the matrix clause "I invited" has taken place (see Merchant 2004), that example too would contain an (albeit concealed) ACD configuration. As (10) shows, however, RD is also licensed in a nonACD context. 4 who Mary did.'

In (10) the elided relative clause is not contained inside its own antecedent. Instead, that antecedent is itself contained in a different sentence (in this case, the first conjunct).

Summing up, in this first section we have shown that although Hungarian relative deletion mainly occurs in ACD contexts, it is by no means restricted to such environments. Moreover, for most speakers either the head of the relative clause has to be focused or the remnant to the right of the relative pronoun has to be modified by the particle is 'also, even'. As pointed out earlier, this is an issue we return to at length in section 5 . In the next section we try to determine the size of the elided constituent in RD.

\footnotetext{
${ }^{4}$ What the examples in (1) and (3)-(5) do show, however, is that unlike in English ACD, the head of the relative clause hosting the ellipsis does not have to be quantified in Hungarian. As this is an issue the scope of which clearly extends beyond this paper, we leave it open here.
} 


\section{How Much Structure Is Elided?}

\subsection{Introduction}

A first question that comes to mind in analyzing relative deletion concerns the size of the elided constituent. ${ }^{5}$ As is well known, ellipsis tends to target NP, VP, or IP (see Lobeck 1995). In the case of RD, the first of these three options can be discarded right away, as the missing part is clearly larger than an NP. The choice between VP and IP on the other hand is not immediately obvious and forms the topic of the present section.

\subsection{VP or IP?}

A straightforward way to determine the size of the elided constituent in RD is look at elements merged inside the IP-domain but higher than VP. Two categories that immediately come to mind in this respect are auxiliaries and adverbs. Given that auxiliaries occupy a VP-external head position in the clausal middle field (say, $\mathrm{T}^{0}$ ), they should survive an ellipsis process that deletes only VP but not one that deletes the whole IP. Consider in this respect the examples in (11) and (12).

$\begin{array}{lllll}\text { Kornél meg } & \text { szokta hívni azt lányt, } \\ \text { Kornél PV } & \text { HAB invite that-ACC the girl-ACC } \\ \text { akit } & \text { Zoltán }[e] . & & \text { a } \\ \text { REL-who-ACC } & \text { Zoltán }\end{array}$

'Kornél usually invites the same girl that Zoltán does.'

$\begin{array}{llll}\text { Kornél meg szokta hívni azt } & \text { a } \\ \text { Kornél } & \mathrm{PV} \text { HAB } & \text { invite that-ACC the } \\ \text { lányt, } & \text { akit } & \text { Zoltán szokott }[e] . \\ \text { girl-ACC } & \text { REL-who-ACC } & \text { Zoltán HAB }\end{array}$

'Kornél usually invites the same girl that Zoltán does.'

The example in (12) is a case of VP-ellipsis (see Bartos 2000), whereas (11) exemplifies RD. Given that the habitual auxiliary szokott is present in the latter but not in the former example, it seems reasonable to conclude that RD deletes a larger chunk of the clausal structure than merely VP. ${ }^{6}$

\footnotetext{
${ }^{5}$ We assume throughout this paper that Hungarian RD should be analyzed as PF-deletion of a fully fledged syntactic structure. For extensive argumentation, see Van Craenenbroeck and Lipták 2005.

${ }^{6}$ In this respect, it is interesting to note that Szczegelniak (2004) discusses data from Polish and Russian similar to those in (11) and (12) and assumes without discussion that both examples are instances of VP-ellipsis, thus forcing him to assume that VP-ellipsis can optionally elide auxiliaries. We hope to return to Szczegelniak's work and to a detailed comparison of Hungarian, Polish, and Russian in future research.
} 
A similar argument can be constructed on the basis of adverb placement. Consider the data in (13) and (14).

$\begin{array}{llrl}\text { ??Kornél fel szokta hívni azt } & \text { a } \\ \text { Kornél } & \text { PV HAB invite that-ACC the } \\ \text { lányt, } & \text { akit } & \text { Zoltán is naponta }[e] . \\ \text { girl-ACC } & \text { REL-who-ACC Zoltán also daily }\end{array}$

'Kornél usually phones the girl whom Zoltán phones daily.'

(14) Kornél fel szokta hívni azt a lányt, akit Kornél PV HAB invite that-ACC the girl-ACC REL-who-ACC

Zoltán is <naponta $>$ fel szokott <naponta $>[e]$.

Zoltán also daily PV HAB daily

'Kornél usually phones the girl whom Zoltán phones daily.'

These data show that, whereas the VP-ellipsis example (i.e., the one containing an auxiliary) can be freely combined with a frequency adverb such as naponta 'daily' (irrespective of whether it precedes or follows the auxiliary), such adverbial modification is dispreferred in RD. Under the assumption that $\mathrm{RD}$ deletes a larger portion of the clausal structure than merely VP, these data follow naturally. The reason why a frequency adverb is disallowed in (13) is because the position normally occupied by such adverbs is contained in the ellipsis site. ${ }^{7}$

A second argument in favor of the hypothesis that RD deletes a larger portion of the clausal structure than merely VP comes from the contrast in (15) and (16).

Kornél AZT
Kornél that-ACC the girl-ACC
ZOLTÁN fog $[e]$.

'The girl who Kornél invited was the one who Zoltán will.'
(16) Kornél AZT A LÁNYT fogja meghívni, akit
Kornél that-ACC the girl-ACC FUT invite-PV REL-who-ACC ZoltÁn (??)fog $[e]$.
Zoltán FUT
'The girl who Kornél will invite is the one who Zoltán will.'

\footnotetext{
${ }^{7}$ Note that we are abstracting away from cases in which the adverb itself is in a focus position. Then the order remnant $<$ adverb is possible in RD (see (i)). As will become clear in section 6 , though, this is exactly what our analysis predicts.

(i) ?Kornél AZT A LÁNYT hívta meg, akit Zoltán TEGNAP $[e]$. Kornél that-ACC the girl-ACC invited PV REL-who-ACC Zoltán yesterday 'The girl who Kornél invited was the one who Zoltán invited YESTERDAY'.
} 
In (15) the antecedent clause and the elliptical clause differ in tense specification. In particular, the former is past, and the latter expresses future tense. In (16) on the other hand, both clauses are future. Interestingly, in this latter case the presence of the future auxiliary fog is slightly degraded in the elliptical relative clause. ${ }^{8}$ Put differently, when there is no tense contrast between the antecedent and elliptical clauses, RD is preferred over VP-ellipsis. This is very reminiscent of a set of data discussed by Merchant (to appear) and illustrated in (17).

(17) a. They studied a Balkan language, but I don't know which $[e]$.

b. ??They studied a Balkan language, but I don't know which they did $[e]$.

The example in (17a) is an instance of sluicing, whereas (17b) represents VP-ellipsis. Just as in (16), however, the auxiliary in the VP-ellipsis case does not express any contrastive information. Merchant suggests that the deviance of $(17 \mathrm{~b})$ is due to the fact that ellipsis tends to delete the largest possible part of the clausal structure. As a result, given that the IP-domain does not contain any contrastive (i.e., nonelidable) material in this example, it is IP-ellipsis, not VP-ellipsis, that applies. It should be clear that this line of reasoning also provides strong support in favor of our hypothesis that RD deletes a larger chunk of the clausal structure than merely VP. In particular, given that in (16) the auxiliary in the elliptical relative clause does not express any contrastive information, it can be elided. This implies that an ellipsis process that deletes a larger portion of the clausal structure is preferred over VP-ellipsis here. ${ }^{9}$

Summing up, we have shown that Hungarian RD deletes more than merely VP. Given that ellipsis tends to target NP, VP, or IP, this leaves IP as the only option. That would imply that $\mathrm{RD}$ is akin to sluicing, the most welldocumented case of IP-ellipsis (see Merchant 2001). This is indeed the claim we defend in the rest of this paper. In the next section we explore this hypothesis somewhat further.

\subsection{Relative Deletion and Non-wh-sluicing}

The hypothesis that RD is actually an instance of sluicing might at first sight seem quite unlikely. Consider again a basic RD example in (18), and compare it with the sluicing example in (19).

\footnotetext{
${ }^{8}$ The exact same kind of slight degradation is also present in example (12). There we glossed over this fact for ease of exposition.

${ }^{9}$ It is not clear whether the deviance of (16) and (17) is really a matter of grammaticality, or merely a sort of redundancy effect. For the argument we are constructing here, however, this does not matter much. What is relevant is that we find the English contrast in (17) replicated in Hungarian in (15) versus (16), thus making more plausible the analysis of the Hungarian facts that we are pursuing.
} 


Kornél AZT A LÁNYT hívta meg,
Kornél that-ACC the girl-ACC invited PV
akit $\quad$ ZOLTÁN $[e]$.
REL-who-ACC Zoltán
'The girl who Kornél invited was the one who Zoltán did.'

(19) János meghívott egy lányt, de nem tudom kit $[e]$. John invited a girl-ACC but not know who-ACC 'John invited a girl, but I don't know who.'

There are two very noticeable differences between these two examples. The first concerns the morphology of the DP-remnant next to the ellipsis site. In the sluicing case it is a $w h$-phrase, whereas in the RD example it is a proper name. The second difference concerns the distribution of these two constructions. As was pointed out by Lobeck (1995:54-62) and Merchant (2001:54-61), sluicing can only delete the IP-complement of an interrogative wh-complementizer. ${ }^{10}$ This means that sluicing is disallowed in relative clauses (see, in particular, Lobeck 1995:57). Given that RD per definition occurs exclusively in relative clauses, the hypothesis that it can be reduced to sluicing will clearly require some extra motivation. In the remainder of this paper we provide precisely such motivation. In particular, we argue that the type of sluicing found in a language depends on the type of $w h$-movement it exhibits. Given that the literature on sluicing has so far focused almost entirely on English, ${ }^{11}$ the general view on this construction is biased and in need of revision. As a first indication of this, consider the Romanian examples in (20) and (21) (from Hoyt \& Theodorescu, to appear). Hoyt and Theodorescu discuss sluicing in Romanian, and they show that unlike in English, Romanian sluicing allows for non-wh-remnants (cf. (21)).

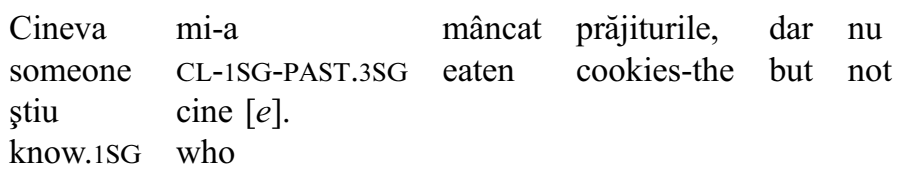

'Someone ate my cookies, but I don't know who.'
(21) Am aflat că cineva a plecat, dar nu
past.1SG learned that someone past.3SG left but not nu ştiu dacă Ion $[e]$.
not know.1SG if Ion
'I found out that someone left, but I don't know if it was Ion.'

\footnotetext{
${ }^{10}$ In English, only the null $\mathrm{C}^{0}$ found in constituent questions qualifies as such.

11 A notable exception is Merchant (2001), who discusses sluicing data from a wide variety of languages. However, given that within these languages he only focuses on sluicing in constituent questions, the bias toward the $w h$-variant of sluicing remains.
} 
If Hoyt and Theodorescu (to appear) are correct in arguing that the example in (21) represents an instance of sluicing, then it is clear that the traditional characterization of this construction needs to be refined. Specifically, it is not the case that sluicing only deletes the IP-complement of interrogative $w h$-complementizers, or that it only has wh-phrases as remnants. In the next section we try to arrive at a new, typologically more accurate theoretical characterization of sluicing.

\section{The Theory: Toward a Sluicing Typology}

\subsection{Introduction}

In this section we lay the foundation for the analysis of Hungarian RD in section 5. In particular, we argue that there is a correlation between the type of wh-movement a language exhibits and the type of remnant that can be found in sluicing. We implement this correlation by means of Merchant's (2001, 2004) analysis of sluicing in terms of the [E]-feature, as this is the most detailed formal account of sluicing to date.

This section is organized as follows. First, in subsection 4.2, we introduce and discuss Merchant's $(2001,2004)$ characterization of sluicing in terms of the [E]-feature. In subsection 4.3 we present a modified version of this theory, which aims to capture the crosslinguistic variation found in sluicing constructions. Finally, in subsection 4.4, we demonstrate how our proposal yields a sluicing typology that can predict the properties of sluicing constructions in a given language based on the type of wh-movement the language displays.

\subsection{Merchant $(2001,2004)$ and the [E]-Feature}

Merchant (2001:55-61, 2004:670-673) argues that the ellipsis process characteristic of sluicing should be implemented by means of a syntactic feature, which he dubs [E]. This feature is merged with the $\mathrm{C}^{0}$-head whose complement is to be elided, and it represents all the relevant properties that distinguish elliptical structures from their nonelliptical counterparts. This approach allows Merchant to directly link the licensing and identification requirements on ellipsis with the phonological effect of nonpronunciation. To see why this is the case, consider the syntactic, phonological, and semantic properties of the [E]-feature in (22) (Merchant 2004:670-673; in (22) ' $\varphi_{\text {IP }}$ ' is the phonological representation of the IP node). ${ }^{12}$

\footnotetext{
12 Note that, strictly speaking, the licensing requirements in (22) are those of $\left[\mathrm{E}_{\mathrm{S}}\right]$ - that is, the variant of the [E]-feature found in sluicing. Other elliptical constructions, such as VP-ellipsis, obviously have other licensing requirements. Given that we are only dealing with sluicing here, we abstract away from this refinement.
} 

a. The syntax of $[\mathrm{E}]$ :
b. The phonology of $[\mathrm{E}]$ :
$\mathrm{E}_{\left[u \mathrm{wh}^{*}, u \mathrm{Q}^{*}\right]}$
c. The semantics of [E]:
$\varphi_{\mathrm{IP}} \rightarrow \varnothing / \mathrm{E}$
$[[\mathrm{E}]]=\lambda \mathrm{p}: \mathrm{e}-\overline{\mathrm{GIVEN}}(\mathrm{p})[\mathrm{p}]$

The formula in (22a) represents the licensing requirements on sluicing. As pointed out earlier (see also footnote 10 ), only the null $\mathrm{C}^{0}$ of constituent questions allows its complement to be elided by sluicing in English. The specification in (22a) captures this intuition by stating that [E] itself is endowed with $[+$ wh, + Q] features. Moreover, these features are marked as uninterpretable (i.e., in need of checking) and strong (marked by the asterisk), which means that they have to be checked in a local relationship, not by means of a long-distance checking mechanism like Agree. As a result, [E] can only occur on the null $\mathrm{C}^{0}$ of constituent questions, which in turn ensures that only the complement of this $\mathrm{C}^{0}$ can be elided. The phonological properties of [E] are represented in (22b). It instructs PF not to parse its complement (or rather, the complement of the head on which it resides). The semantics of [E] in (22c) encodes the identification or recoverability requirement on the elided phrase. Roughly, an expression is e-GIVEN when it has an appropriate antecedent (see Merchant 2001:23-37 for more detailed discussion of e-GIVENness). The formula says, then, that semantic composition cannot proceed if the complement of [E] is not e-GIVEN. In other words, only phrases that have an appropriate antecedent (i.e., whose content is recoverable from this antecedent) can be elided.

This concludes our introduction into Merchant's $(2001,2004)$ theory of sluicing. In the next subsection we propose a modification of the syntactic requirements of the [E]-feature, so as to allow for the crosslinguistic diversity found in sluicing constructions.

\subsection{Modifying Merchant's Account}

We want to argue that Hungarian sluicing differs from its English counterpart in that it is licensed in a different set of syntactic environments. It is clear that if we want to implement this variation in terms of the [E]-feature, it is the syntactic properties of this feature we will have to focus on. Specifically, there are no differences between the two languages when it comes to the phonological or semantic properties of sluicing. In both cases, sluiced clauses are not pronounced and require a salient antecedent. To prevent our modification of Merchant's theory from becoming a pure technicality, however, it would be desirable if we could link the different syntactic specifications the [E]-feature will have in Hungarian and English to independent properties of these two languages. In this respect we want to propose the following correlation:

\section{The $W h /$ Sluicing Correlation}

The syntactic features that the [E]-feature has to check in a certain language are identical to the strong features a $w h$-phrase has to check in a regular constituent question in that language. 
Let us consider the consequences of this correlation for English and Hungarian. For English, nothing much changes. Under the (fairly uncontroversial) assumption that a wh-phrase in a regular constituent question has to check strong $[+w h,+Q]$ features (say, operator and clause typing features; see Van Craenenbroeck 2004:31-51 for detailed discussion), the $W h$ /Sluicing Correlation predicts that the syntactic requirements of [E] should be exactly as outlined in (22a). For Hungarian, however, the situation is quite different. As is well known, Hungarian wh-movement does not target Spec,CP, but rather a focus position in the high middle field of the clause (Spec,FocP) (see É. Kiss 1987, Bródy 1995). This means that the only strong feature a $w h$-phrase checks in a Hungarian constituent question is $[+$ focus], or more generally $[+\mathrm{Op}$ (erator)]. Accordingly, the syntactic requirement of $[\mathrm{E}]$ in Hungarian should not be as in (22a), but rather as in (24).

$$
\text { The syntax of }[\mathrm{E}] \text { in Hungarian: } \quad \mathrm{E}_{[u \mathrm{Op} *]}
$$

This implies that in Hungarian [E] is not only fully licensed when it resides on a head whose specifier is occupied by a moved $w h$-phrase (as in English), but rather in every syntactic context where an operator/variable dependency is created. In the next section we show how this claim can account for the fact that Hungarian does, but English does not, allow for RD. As a first illustration of a prediction made by the formula in (24), however, consider the example in (25).

$\begin{array}{llllll}\text { János } & \text { meghívott } & \text { valakit } & \text { és azt } & \text { hiszem } \\ \text { János } & \text { PV.invited } & \text { someone-ACC } & \text { and } & \text { that-ACC } & \text { think } \\ \text { hogy } & \text { BÉLÁT }[e] . & & & & \\ \text { that } & \text { Béla-ACC } & & & & \end{array}$

'János invited someone and I think it was Béla he invited.'

In this example the ellipsis of IP is licensed not by a wh-phrase, but rather by a non-wh-focus (cf. also the Romanian example in (21)). Given that such an element checks an operator feature in Spec,FocP, the formula in (24) correctly predicts that the complement of $\mathrm{Foc}^{0}$ can be elided. The fact that such non-wh-sluicing is not allowed in English is due to the fact that the [E]-feature has more stringent syntactic requirements in this language, requirements that can only be checked by a $w h$-phrase in a constituent question.

\subsection{The Bigger Picture: A Typology of Sluicing}

In the previous subsection we argued that there is a correlation between the type of wh-movement attested in a language and the type of sluicing it 
Table 1. Typology of $w h$-movement and sluicing constructions

\begin{tabular}{lll}
\hline Type of $w h$-movement & $\begin{array}{l}\text { Syntactic properties } \\
\text { of the [E]-feature }\end{array}$ & Sample languages \\
\hline $\begin{array}{l}\text { Movement to Spec,CP } \\
\text { Movement to Spec,FocP }\end{array}$ & $\begin{array}{l}\mathrm{E}_{\left[u \mathrm{wh}^{*}, u \mathrm{Q}^{*}\right]} \\
\mathrm{E}_{\left[u \mathrm{Op}^{*}\right]}\end{array}$ & $\begin{array}{l}\text { English, Dutch, German } \\
\text { Hungarian, Spanish, Basque, } \\
\text { Polish, Russian, Hebrew }\end{array}$ \\
$W h$-in-situ & No sluicing & Korean, Japanese, Chinese \\
\hline
\end{tabular}

exhibits. If we extrapolate this hypothesis to a wider range of languages, we arrive at the typology of sluicing constructions shown in Table 1.

In this taxonomy there are three types of languages. The first two (exemplified by English and Hungarian) have already been discussed. The third one concerns $w h$-in-situ languages. In these languages, a $w h$-phrase in a constituent question does not check any strong features. Accordingly, it is not possible to determine the syntactic requirements of the [E]-feature in these languages and sluicing is predicted not to occur. This conclusion accords nicely with the growing body of literature on sluicing-like constructions in languages like Japanese and Korean, which claims that these constructions are in fact derived from clefts, not from $w h$-questions (see especially Fukaya \& Hoji 1999 for discussion).

It should be clear that the classification in Table 1 represents a research program the scope of which extends beyond this paper. In particular, each language should be classified according to the type of wh-movement it exhibits and this classification should be crossreferenced against the types of (clausal) ellipsis attested in these languages. Interestingly, our first preliminary explorations suggest that the general approach is on the right track. Not only do the East Asian wh-in-situ languages fit in nicely, but Polish, Hebrew, and Russian seem to pattern like Hungarian. In particular, all three of these languages display wh-movement to a clause-internal focus position, and all three have an elliptical construction that is remarkably similar to Hungarian RD. ${ }^{13}$ In this respect, it is particularly interesting to see that Grebanyova (2006), when discussing sluicing in Russian, independently from the present paper arrives at the conclusion "that not only an interrogative $\mathrm{C}^{0}$ can license IP-deletion, but a focus head $\left(\mathrm{Foc}^{0}\right)$ can do it as well.... Thus, not only CP

\footnotetext{
13 See Szczegelniak 2004 for the Polish and the Russian data, and thanks to Omer Preminger (p.c.) for the Hebrew facts. Recall from footnote 6 that we do not follow Szczegelniak in analyzing this construction as VP-ellipsis. The only difference that we have encountered so far between Polish and Hungarian is the fact that in Polish, RD does seem to be restricted to ACD-contexts (see example (10) and surrounding discussion).
} 
occupants can survive this deletion process." As pointed out earlier, though, we leave the further fleshing out of this research program as a topic for future work. $^{14}$

\section{The Analysis: RD as Sluicing}

\subsection{The Syntax of Sluicing in Hungarian}

According to our proposal, Hungarian sluicing can occur in every syntactic context where an operator/variable-dependency is created, due to the $\left[u \mathrm{Op}^{*}\right]$ specification of the [E]-feature in this language. This specification results in two important differences between English sluicing on the one hand and Hungarian sluicing on the other.

First, from this hypothesis it follows that complements of functional heads whose specifier hosts operators can freely undergo sluicing in Hungarian. There are two types of functional projections that host operators in the left periphery: the unique FocP projection, which either hosts a contrastive focus or a $w h$-item; and DistPs, which host distributive quantifiers (É. Kiss 1987, Brody 1995, Szabolcsi 1997). This means that sluicing is predicted to occur not only in constituent questions, leaving behind a question word as remnant, but also in declarative clauses, leaving behind a focused phrase or distributive quantificational items. Example (25) from section 4.3 (repeated as (26a)) provides an example with a focused remnant, and (26b) with a quantificational one:

$$
\begin{array}{lllll}
\text { a. János } & \text { meghívott valakit } & \text { és azt } & \text { hiszem, } \\
\text { János } & \text { PV-invited } & \text { someone-ACC } & \text { and that-ACC } & \text { think } \\
\text { hogy } & \text { BÉLÁT }[e] . & & & \\
\text { that Bélá-ACC } & & &
\end{array}
$$$$
\text { 'János invited someone and I think it was Béla whom he invited.' }
$$

b. Tudtam, hogy János meghívott néhány embert, knew that János PV-invited some people-ACC de nem tudtam, hogy mindenkit $[e]$. but not knew that everyone-ACC 'I knew that János invited some people, but I didn't know that he invited everyone.'

The specification of the [E]-feature as $\left[u \mathrm{Op}^{*}\right]$ can account for these examples in the required manner. To illustrate, take (26a). The uninterpretable and strong operator feature on $[\mathrm{E}]$ requires that $[\mathrm{E}]$ attaches to the

\footnotetext{
${ }^{14}$ Another question raised by our taxonomy of sluicing constructions concerns multiple whmovement languages. Specifically, if Rudin (1988) is correct in assuming that in a language like Bulgarian, one wh-phrase moves to Spec,CP, and all the others to Spec,FocP, it remains to be determined what the syntactic feature specification of the [E]-feature is in such languages.
} 
head that entertains a local relationship with an operator constituent (the focused item), namely $\mathrm{Foc}^{0}$. As a result of [E] merging here, the complement of $\mathrm{Foc}^{0}$ is PF-deleted, and the only surviving phonological material in the elliptical clause is the complementizer hogy 'that' and the focus Bélát 'Béla-ACC'. The derivation of this example can be represented as in $\left(26 a^{\prime}\right)$ :

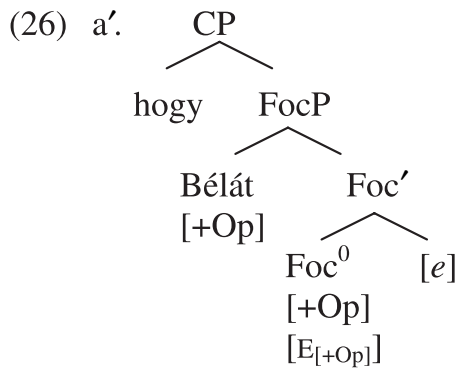

The same configuration can be found in (26b), with DistP taking the place of FocP.

The second consequence of our proposal concerns the amount of structure contained in the ellipsis site. The difference with English here follows from the syntactic properties of left peripheral functional projections in Hungarian. Because complementizers in Hungarian do not have strong operator features (i.e., they do not host overt operators in their specifier, see É. Kiss 1987, Brody 1995, among others), the [E]-feature does not relate to the complementizer layer in this language in any way. This results in the fact that Hungarian sluicing affects a lower section of the left periphery, the section that is embedded under the complementizer hogy 'that'. This is why the remnant in Hungarian can be preceded by an overt complementizer, as was the case for the examples in (26).

Even more importantly from our present perspective, the fact that the complementizer layer is not involved in the mechanism of sluicing also means that sluicing is not restricted to just the sole clause type where questions can occur, but that it can be found in other types of clauses as well. This, we want to claim, is exactly what gives rise to RD: in RD we have sluicing in a nonargumental embedded clause (i.e., a relative clause). The complementizer layer of relative clauses only differs from that of argumental embedded clauses in that it contains a relative pronoun instead of a finite complementizer. This, however, is immaterial to whether sluicing can succeed, as sluicing is completely "blind" to the complementizer layer in Hungarian. Relative clauses, just like argumental clauses, contain FocP and DistP operator positions in the left periphery (Kenesei 1994) and thus can license sluicing of the complements of these projections. The feature specification of [E] introduced in (24) thus captures the facts of RD as well, 
without any extra assumption. In the following two subsections, we show in more detail how.

\subsection{RD with Focused Remnants}

Let us start our analysis with the cases of RD in which the head of the relative clause is focused, as in (1), repeated here as (27).

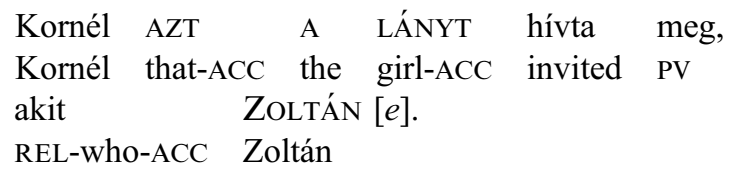

'The girl who Kornél invited was the one who Zoltán did.'

As we indicate through the use of small caps, the remnant item (Zoltán) in this $\mathrm{RD}$ construction is also focused (see also note 2). That the remnant is a focused item can be seen not only from the fact that it necessarily receives focal stress/pitch accent, characteristic of preverbal focus, but also from the fact that the nonelliptical version of the same sentence (which has the same interpretation as (27)) obligatorily contains preverb-verb inversion in the relative clause, a syntactic indicator of focusing:

$\begin{array}{lllll}\text { Kornél AZT } & \text { A } & \text { LÁNYT } & \text { hívta meg, } \\ \text { Kornél that-ACC the girl-ACC } & \text { invited } & \text { PV } \\ \text { akit } & \text { ZOLTÁN } & \text { hívott } & \text { meg/*meghívott. } \\ \text { REL-who-ACC } & \text { Zoltán } & \text { invited } & \text { PV/ PV-invited }\end{array}$

'The girl who Kornél invited was the one who Zoltán did.'

Our analysis accommodates the focused nature of the remnant here in the same way as it did in the case of (26a). The focused remnant (Zoltán) is an operator constituent, which is left behind when sluicing applies to the relative clause as a result of $[\mathrm{E}]$ merging with the $\mathrm{Foc}^{0}$ head that hosts the remnant in its specifier. The structure of this sentence, shown in (29), is exactly the same as the one in $\left(26 \mathrm{a}^{\prime}\right)$. The only difference we find concerns the lexical content of the CP domain: in (29) we have a relative pronoun instead of a finite complementizer.

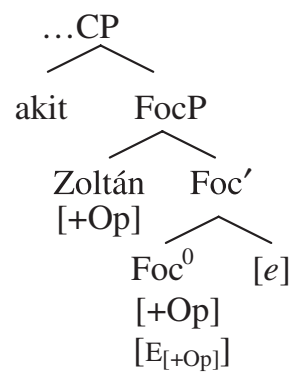


As we indicated in section 2, if the remnant occurs on its own, unadorned with the particle is 'also, even', the majority of speakers requires that the relative-clause head in the matrix clause be focused as well. Without focus on the relative-clause head, these speakers find the sentence degraded or unacceptable:

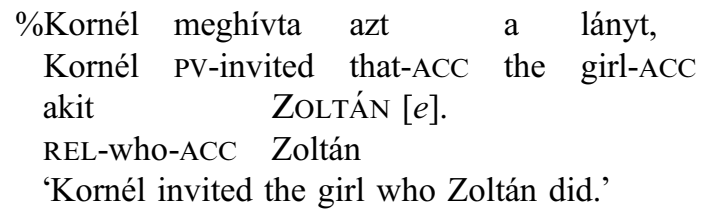

We believe this follows from our treatment of (28) as well, most notably from the fact that we assign focus status to the remnant constituent. To see why this is the case, we need to step back from sluicing for a minute and introduce the phenomenon of focus percolation that characterizes Hungarian relative clauses in general, both headed and headless ones. What we refer to as focus percolation boils down to the fact that the interpretation and syntactic distribution of Hungarian relative clauses is sensitive to whether they contain a focused constituent. If a relative clause contains a focus element, the relative clause as a whole (in the case of free relatives) or the modified head (in the case of headed relatives), strongly prefers to be focused as well. We illustrate this phenomenon with a headed relative in (31).
a. ?? János megette azt a levest amit János PV-ate that-ACC the soup-ACC REL-what-ACC MARI készített el.
Mari prepared PV
'János ate the soup that MARI prepared.'
b. János AZT A LEVEST ette meg amit János that-ACC the soup-ACC ate PV REL-what-ACC MARI készített el. Mari prepared PV 'It was the soup that MARI prepared that János ate.'

As these examples show, the presence of focus on Mari within the relative clause forces the presence of focus on the head of the relative clause as well: the fully grammatical example has azt a levest 'that soup' in the focus position in (31b), interpreted as contrastive focus. Without focus on the 
head of the relative, the sentence becomes considerably degraded, as (31a) shows. ${ }^{15}$

Returning to the analysis of $\mathrm{RD}$, focus percolation now provides an explanation for the pattern in (3)-(5) and that in (27): it is focus on the remnant element that forces the focus on the relative-clause head as well in these examples. The remnant is required to be focused, because sluicing/the [E]-feature is licensed only in operator-variable constructions, and in these examples it is a focused remnant that provides the licensing operator for sluicing. The focused nature of the remnant is then passed on to the whole relative clause via the standard mechanism of focus percolation, which explains why the head of the relative also behaves as syntactic and semantic focus itself.

Focus percolation, we contend, also underlies the subtle speaker variation that we found in the domain of RD. The minority of speakers who accept unadorned remnants without focusing the head of the relative clause (i.e., for whom (30) is grammatical), tend to be the speakers who allow for the relaxation of focus percolation. For this set of speakers, the presence of a focus internal to the relative clause does not strongly entail that the head of the relative clause also be focused: these speakers judge examples like (31a) grammatical in many contexts. As a result, these speakers can accommodate focused remnants in $\mathrm{RD}$ without focusing the head of the relative as well.

In this section we accounted for examples of $\mathrm{RD}$ with an unadorned remnant. We argued that such remnants are always focused items and license sluicing, as predicted by our analysis, given that focus is an operator-variable construction. We also explained why for the majority of speakers these

${ }^{15} \mathrm{We}$ are not aware of any analysis of focus percolation in the syntactic/semantic literature. Although we do not attempt to give one here, either, we would like to point out that the phenomenon seems to us to be partly semantic in nature. The percolation property of Hungarian relative clauses is reminiscent of the quantifier scope phenomena in English free relative clauses that were discussed by Moltmann and Szabolcsi (1994). Consider in this respect the example in (i).

(i) Some professor or other read what every boy read.

In this example, the relative clause internal universal quantifier every boy can scope over the existential some professor or other, due to the fact that free relatives in English are what Moltmann and Szabolcsi call "layered quantifiers." These are quantifiers that inherit the scopal abilities of their internal wide scope quantifier. Due to this inheritance phenomenon the free relative clause comes to behave as a universal quantifier itself and interacts scopally with other elements in the clause it occurs in. We believe that Hungarian (31) instantiates a similar phenomenon: the relative clause as a whole "inherits" the focus property from its internal focus constituent.

It must be mentioned that next to the above-described focus percolation process, there might exist other, arguably non-semantic-based mechanisms that license the occurrence of focus inside relative clauses. As István Kenesei points out to us, next to focus on the head of the relative clause (as in (31b)), focus on any other main-clause material can also license relative-internal focus:

(ii) JÁNOS ette meg azt a levest, amit MARI készített el. János ate PV that-ACC the soup-ACC REL-what-ACC Mari prepared PV 'It was John who ate the soup that MARI prepared.'

As far as we could ascertain, speakers for whom (i) is grammatical can also use RD in the same licensing context. We leave the specifics of these facts and the analysis of focus percolation for future research. 
examples involve focus on the head of the relative, too, linking this to the independent phenomenon of focus percolation that exists in Hungarian relative clauses. In the next subsection we turn our attention to the RD with remnants that are followed by an is 'also, even' particle.

\section{$5.3 R D$ with Is 'Also, Even'-marked Remnants}

As (6)-(8) illustrated, when RD occurs inside a relative clause whose head is not focused, the majority of speakers prefer to spell out is 'also, even' after the remnant. Consider (6) again, repeated here.

\begin{tabular}{|c|c|c|c|c|c|}
\hline Kornél & meghívta & azt & $\mathrm{a}$ & lányt, & akit \\
\hline $\begin{array}{l}\text { Kornél } \\
\text { Zoltán }\end{array}$ & $\begin{array}{l}\text { PV-invited } \\
\% \text { (is) }[e] .\end{array}$ & that-ACC & the & girl-ACC & REL-who-ACC \\
\hline Zoltán & also & & & & \\
\hline
\end{tabular}

'Kornél invited the girl who Zoltán did (too).'

The prediction made by the current theory with respect to examples such as the one in (32) is clear. Specifically, if Hungarian RD is indeed an instance of sluicing licensed by a $[+u \mathrm{Op} *]$-marked [E]-feature, then $i s$-phrases should be syntactic operators as well. As we will show, this prediction is borne out.

The quantificational nature of is 'also, even'-marked items manifests itself in various ways in the grammar of Hungarian. First of all, distributional facts indicate that $i s$-phrases occupy a specific position in the so-called quantifier field of the left periphery, to the left of focused constituents and other quantificational items (Kenesei 1986, Brody 1990, Szabolcsi 1997). We will refer to this position as Spec,Dist ${ }_{\text {is }} \mathrm{P}$, and we take is to spell out the functional head Dist ${ }_{\text {is }}^{0}$, following Brody (1990). Apart from their characteristic placement among quantifiers, the operator status of $i s$-phrases can clearly be seen in parasitic-gap licensing as well. Parasitic gaps are only licensed by operatorvariable relations in Hungarian (É. Kiss 2001). The fact that is-phrases, just like focused items, license these (see (33a)) indicates that they instantiate an operator-variable relationship.

$\begin{array}{llll}\text { a. János a könyveket } & \text { is } s_{\mathrm{i}} \text { eldobta } t_{\mathrm{i}} \\ \text { János the books-ACC } & \text { also PV-threw } \\ \text { [mielőtt } & \text { elolvasta } & \left.\text { volna } p g_{\mathrm{i}}\right] \\ \text { before } & \text { read-PAST-3SG } & \text { COND }\end{array}$

'János also threw the books away before reading.'

b. A KÖNYVEKET $T_{i}$ dobta el János $t_{\mathrm{i}}$ [mielött the books-ACC threw PV János before elolvasta volna $\left.p g_{\mathrm{i}}\right]$. read-PAST-3SG COND

'It was the books that János threw away before reading.' 
The last argument we provide for the quantificational/operator nature of is 'also, even' phrases comes from their interpretation: is-phrases are obligatorily distributive in Hungarian, as shown in (34) (Szabolcsi 1997).
a. Péter is felemelte az asztalt.
Péter also lifted the table-ACC
'Péter also lifted the table (on his own/*together with others).'
b. Hat fiú is felemelte az asztalt. six boys also lifted the table-ACC
'As many as six boys lifted up the table (separately/*collectively).'

Péter is 'Péter, too' in (34a) cannot be interpreted as 'Péter being part of a group of people who lifted the table', and similarly, hat fiu is 'as many as six boys' cannot receive a collective interpretation. As Szabolcsi argues, obligatorily distributive elements are restricted to the quantificational field in Hungarian (termed DistP projections) because they are essentially quantificational in nature. ${ }^{16}$

With the operator nature of $i s$-expressions firmly established, we can now return to the analysis of $i s$-marked remnants in RD. Given that the is-phrase is an operator, our proposed account is applicable here as well, along the same lines as the analysis of focused remnants in (29) above. The [E]-feature responsible for sluicing attaches to the syntactic head whose specifier hosts the operator phrase and licenses the deletion of everything else in its complement. The resulting configuration of our sluicing example is shown in (35). ${ }^{17}$

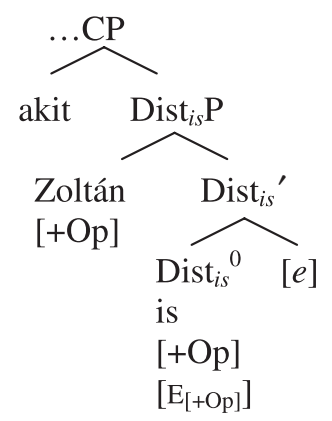

\footnotetext{
16 "Essentially quantificational" DPs are defined semantically as items that do not denote (singular or plural) individuals and whose determiners are nonintersective (i.e., universal, proportional, or at least presuppositional). According to Partee (1995) all essentially quantificational DPs are distributive.

${ }^{17}$ Note that if $i s$ indeed spells out the head of Dist ${ }_{i s} \mathrm{P}$, this instance of ellipsis differs from "regular" (i.e., $[+w h])$ sluicing in that the head triggering the ellipsis is itself spelled out (thanks to Jason Merchant [p.c.] for raising this issue, and see Merchant 2001:74-82 for the observation with respect to $w h$-sluicing). Nothing in our story hinges on this assumption, though. Specifically, it might well be (pace Brody 1990) that is is a suffix attached to the phrase in Spec,Dist ${ }_{i s} \mathrm{P}$. In that case, the head of this projection would remain silent, exactly as in wh-sluicing. See Van Craenenbroeck and Lipták 2006, though, for morphological evidence that the Foc ${ }^{0}$-head can contain overt morphological material in Hungarian sluicing.
} 
This configuration readily explains why many speakers require $i s$ to be spelled out if the head of the relative clause is not focused (cf. examples (6)(8)). Recall that for these speakers, focus percolation is obligatory, which means that if the head of the relative clause is not focused, there cannot be a focus inside the relative clause (otherwise this focus would percolate). This entails that in cases where the head of the relative is not focused, the remnant is not a focus constituent. Because sluicing is only licensed with operator remnants, however, the operator status of the remnant needs to be ensured by other means. Spelling out the quantificational is particle does exactly this job: it turns the remnant into an operator constituent and thus licenses sluicing. This is why speakers require the presence of is in these contexts.

Our analysis of sluicing in terms of an [E]-feature with $\left[u \mathrm{Op}^{*}\right]$-content seems to make the right predictions for the RD facts discussed so far. Sluicing in relative clauses is restricted to cases in which the remnant is an operator: a focus or an $i s$-phrase. Note by the way that ordinary universal quantifiers, inhabitants of DistP positions, are also allowed in RD constructions, just like $i s$-phrases are. The following specimen of RD contains a run-of-the-mill universal quantifier as remnant:

(36) Péter AZT hívta meg, akit
Péter that-ACC invited PV REL-who-ACC everyone
'The person Péter invited was the person who was invited by
everyone.'

Again, sluicing in this relative clause is licensed by the operator nature of the remnant mindenki 'everyone', just as in the argumental embedded clause in (26b).

Summarizing, in this section we presented an analysis of RD in Hungarian with the help of our new taxonomy of sluicing constructions. We successfully showed that in this language, where the overt syntax of wh-movement coincides with that of other operator material like focus, is-phrases, and universal quantifiers, sluicing is also allowed with these other types of operators in both argumental and nonargumental clauses. This concludes our analysis of RD in terms of sluicing. In the following section we discuss some further correct predictions made by our account.

\section{Further Predictions and Extensions of the Analysis}

\subsection{Introduction}

This section serves a double purpose. On the one hand, we want to examine some further predictions our analysis makes with respect to RD in Hungarian. Specifically, we will show that topics and speaker-oriented adverbs, which are not syntactic operators and hence unable to license [E], are not licit RDremnants. On the other hand, we want to briefly explore to what extent our 
analysis can shed new light on elliptical processes such as stripping or fragment answers in a language like English. Though that part of the discussion will be more tentative, the potential benefits, we argue, are substantial.

\subsection{Topics and Speaker-oriented Adverbs in Hungarian RD}

The previous two sections have argued that modifying the syntactic feature content of Merchant's (2001) [E]-feature enables us to neatly account for the observed patterns of RD in Hungarian. As we show in this section, the proposal successfully covers other data in the domain of RD as well.

The first such set of data concerns the impossibility of sluicing with topic remnants. Topics are left peripheral constituents that precede operators in DistP and FocP in Hungarian (É. Kiss 1987, Brody 1995, Szabolcsi 1997), according to the following schematic structure:

$$
[\mathrm{CP}[\mathrm{TopP} * \text { topics }[\operatorname{DistP} *[\mathrm{FocP}[\ldots]]]]
$$

Topics are necessarily referential constituents that have no operator properties. They do not interact scopally with other constituents in the clause (they always take highest scope in a sentence), and they do not license parasitic gaps, either (cf. (38) and (33)).

$$
\begin{aligned}
& \text { *János a könyveket }{ }_{\mathrm{i}} \text { eldobta } t_{\mathrm{i}} \text { [mielött elolvasta volna } p g_{\mathrm{i}} \text { ]. } \\
& \text { János the books-ACC PV-threw before read-3SG COND } \\
& \text { 'János threw away the books before reading.' }
\end{aligned}
$$

If we are right in saying that $\mathrm{RD}$ is an instance of sluicing under a [ $\left.u \mathrm{Op}^{*}\right]$ specified [E]-feature, we predict that topics are not available as remnants in RD in Hungarian, not being operators. This prediction is borne out.

To show that topics cannot be the sole remnants in sluicing constructions, we need to turn to matters of pronunciation. A clear difference between topics and foci lies in their accentual properties: foci obligatorily receive focal stress/ pitch accent, whereas topics do not. Using this property we can test whether a remnant can be topic, by leaving it without pitch accent. This, however, is not licit in RD. Our initial example from (1), (repeated here as (39)) is ungrammatical if a (lexically nonquantificational) remnant has no pitch accent (indicated here by even accentuation on akit 'who', Zoltán and all main-clause material):

*'Kornél 'meghívta 'azt a 'lányt,
Kornél PV-invited that-ACC the girl-ACC
'akit 'Zoltán $[e]$.
REL-who-ACC Zoltán
'Kornél invited the girl who Zoltán did.'


This shows that Zoltán cannot be a topic constituent: if it was, it could stay nonaccented, contrary to fact.

Next to matters of pronunciation we can also resort to other means to show that topiclike constituents cannot be remnants. Demonstration for this comes from the distribution of adverbs. In Hungarian, evaluative speaker-oriented adverbs show characteristics of topics both in their distribution and in their accentuation: they occur as high as topic constituents and are necessarily unstressed. Consider such an evaluative adverb in (40).

$\begin{array}{lll}\text { Péter biztosan AZ AUTÓJÁT } & \text { vezette. } \\ \text { Péter surely the car-POSS.3SG-ACC } & \text { drove } \\ \text { 'It was surely his car that Péter drove.' } & \end{array}$

In (40) we see that when biztosan 'surely' occurs to the left of material that is contained in a focus projection, only the speaker-oriented interpretation is available. When this adverb is the focus itself, the speaker-oriented interpretation ceases to be available and the adverb is interpreted as a manner adverb (É. Kiss 1992). This is shown in (41).

$\begin{array}{lllll}\text { Péter } & \text { BIZTOSAN } & \text { vezette } & \text { az } & \text { autóját. } \\ \text { Péter-NOM } & \text { confidently } & \text { drove } & \text { the } & \text { car-POSS.3SG-ACC }\end{array}$

'Péter drove his car confidently.'/*'It was sure that Péter drove his car.'

The clear interpretive contrast between (40) and (41) is an ideal testing ground for finding out which of these two positions is available to this item when it occurs as the remnant in RD. As (42) shows, in RD contexts only the manner adverb reading is possible. ${ }^{18}$
Az vezet jól, aki
BIZTOSAN.
that drives well REL-who confidently
'The person who drives well is the one who drives confidently.'
*'The person who drives well is the one who surely drives.'

The fact that the speaker-oriented interpretation is unavailable indicates that $\mathrm{RD}$ does not allow for its remnant to be placed as high as topics. This is in accordance with our claim that sluicing is licensed by operator material, which occurs lower than topics in the left periphery. ${ }^{19}$

\footnotetext{
${ }^{18}$ One of the speakers we consulted rejected the example in (42) on any reading. We assume that an independent factor is interfering here.

${ }^{19}$ Note that the data in (40)-(42) in combination with Cinque's (1999) theory of adverb placement also strongly suggest that biztosan is not in its base position in (42). As Cinque shows, manner adverbs are base-generated lower in the structure than speaker-oriented ones. The fact that it is only the lower reading that shows up in RD suggests that movement is involved in its derivation. Thanks to Marcel den Dikken for pointing this out to us.
} 
The fact that sluicing affects a lower portion of the clause than the position of topics in turn predicts that it should be possible to find cases of RD in which the operator that licenses sluicing is preceded by a topic. Such cases of multiple remnants can indeed be found, as we anticipated in footnote 7:

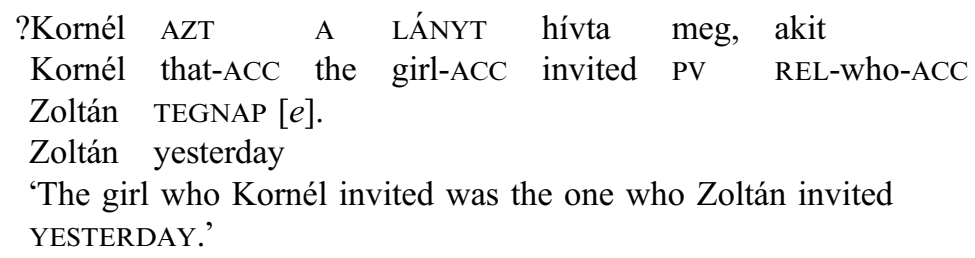

The relative clause in this case contains three elements: the relative pronoun, the topic Zoltán, and the focus operator tegnap 'yesterday'. It is the focused element that licenses sluicing. The other two preceding it are found in a position higher than that affected by sluicing and thus escape deletion. Such multiple constituent sluices are slightly less preferred to single-remnant ones, but they are by no means ungrammatical. We take this as evidence for our claim that sluicing in Hungarian affects the lower, operator portion of the left periphery in this language and leaves the higher regions of the left periphery untouched.

\subsection{Stripping and Fragment Answers}

Although English differs from Hungarian in that it does not have RD - that is, it does not allow the complement of an operator-related head to be elided in a relative clause (see (44)) - in main clauses it has two constructions that seem to show certain parallels with the Hungarian data we have been discussing so far. Consider the examples in (45) and (46).

*John gave the same book to Mary that TO BILL [e].

John talked to Mary yesterday and Bill [e] too.

Q: What did Carlos eat?

A: Two bananas [e].

The sentence in (45) illustrates a construction usually referred to as stripping, whereas the reply in the dialogue in (46) is a fragment answer. What is interesting about these data from the perspective of the present paper is that both constructions involve a pattern that is highly similar to the one we described for Hungarian RD: a focused non-wh XP is found next to a clausal ellipsis site. In fact, this is precisely the analysis Merchant $(2003,2004)$ argues at length for when discussing these constructions. The crucial difference with 
the Hungarian data appears to be that both stripping and fragment answers are categorically excluded in embedded clauses.

*John talked to Mary yesterday and I think that Bill [e] too.
Q: What did Carlos eat?
A: *I think that two bananas [e].

In light of these data one could be tempted to give up the idea of a unified account for Hungarian RD (i.e., sluicing) on the one hand and stripping/ fragment answers on the other. That is not the tack we will take, however. In particular, we believe that the specific implementation we have proposed for the crosslinguistic variation of sluicing constructions allows for enough leeway to incorporate data such as those in (45)-(48). Space considerations prevent us from going into this issue in detail here, but we want to sketch two possible scenarios such an analysis could take. We hope to be able to give a more detailed account of these data in future work.

One way to incorporate the main-clause restriction on stripping and fragment answers is to slightly modify the syntactic feature requirement of the [E]-feature in English. Consider again the requirement we arrived at in section 4.2 , repeated here.

$$
\text { The syntax of [E] in English: } \quad \mathrm{E}_{\left[u \mathrm{wh}^{*}, u \mathrm{Q}^{*}\right]}
$$

To be fully licensed, the [E]-feature in English has to check both an operator and a question feature. As we pointed out, this implies that only the complement of the $\mathrm{C}^{0}$-head whose specifier hosts a fronted wh-phrase can license sluicing. Suppose, however, that we replace the [+Q]-feature with a more general clausetyping feature. ${ }^{20}$ For embedded clauses, this would arguably not make much of a difference. In embedded contexts, clause typing is linked to selection, and although there are verbs that select an interrogative as complement, there are no verbs that select a CP in which a focus has been fronted. In main clauses, however, the situation is different. There, fronted non-wh XPs can serve to mark a declarative clause (this is particularly clear in a V2 language like Dutch). As such, the main versus embedded asymmetry of ellipsis processes in English-type languages would fall out from the modified feature content of the [E]-feature.

Another option would be to leave the syntactic requirement of the [E]feature in English-type languages as is (i.e., as in (49)) and to derive the main versus embedded asymmetry in these languages from the properties of whmovement, in accordance with the $\mathrm{Wh}$ /Sluicing-Correlation in (23). Recall that that principle states that the syntactic requirements of the [E]-feature in a particular language depend on the strong features a wh-phrase checks in

\footnotetext{
${ }^{20}$ In this respect it is worth pointing out that Fujii and Ono (2005) argue that sluicing can also apply in exclamatives in English.
} 
a regular constituent question in that language. Suppose, however, that such a correlation is not refined enough. In particular, if in a certain language the landing site of $w h$-phrases differs in main and embedded constituent questions, then the feature specification of the [E]-feature should reflect this difference. Interestingly, Den Dikken and Giannakidou (2002) and Den Dikken (2003) argue for precisely such a difference in English. Specifically, based among others on word-order facts and the distribution of wh-the-hell, they claim that whereas in embedded constituent questions wh-phrases in English move all the way to Spec, CP, in matrix questions they remain in Spec,FocP. ${ }^{21}$ If we extrapolate this to the syntactic requirements of the [E]-feature in English, we obtain the following picture:
a. The syntax of embedded [E] in English:
$\mathrm{E}_{\left[u w h^{*}, u \mathrm{Q}^{*}\right]}$
b. The syntax of main clause [E] in English:
$\left.\mathrm{E}_{[u w h}{ }^{*}\right]$

In other words, in embedded questions [E] has to check both a question and an operator feature (represented in (50a) as [+Q] and [+wh], respectively), but in matrix $w h$-questions it only checks an operator feature. That implies that-like Hungarian-type languages_-English main clauses allow for more elliptical constructions than embedded ones do. In other words, the present line of reasoning is able to account for the contrast between $(45) /(46)$ and $(47) /(48)$.

Summing up, although the two scenarios sketched above leave many questions unanswered, ${ }^{22}$ it should be clear that the possible gains of this approach are substantial. In particular, if our approach is on the right track, it paves the way for a unified theory of clausal ellipsis that incorporates not only the crosslinguistic diversity of sluicing but also related constructions such as stripping and fragment answers.

\section{Summary}

In this paper we extended the empirical domain of sluicing constructions by analyzing new data from Hungarian, in which sluicing affects the content of a relative clause and leaves behind an operator remnant. In doing so we proposed an analysis that takes after that of Merchant $(2001,2004)$ but is crucially new in some respects. Our basic innovation lies in the relativization of the syntactic feature content of [E], the feature responsible for the deletion process, to other properties of a given language - most notably, to the feature content of $w h$-phrases in questions. Earlier proposals assumed a crosslinguistically uniform specification for the [E]-feature in terms of [+wh,+Q] subfeatures, designed to restrict the occurrence of sluicing to question clauses

\footnotetext{
21 See Den Dikken 2003 for a technical implementation of this difference in terms of Chomsky's (1995:234) characterization of the nature of strong features.

${ }^{22}$ For example, whereas sluicing can repair island violations (Ross 1969, Merchant 2001), fragment answers cannot (Merchant 2004). See Merchant 2004:705-715 for a possible account, which might be compatible with our analysis.
} 
with a null complementizer in English. We showed that this feature specification is insufficient for languages where sluicing involves non-wh remnants and can involve overt complementizers of various sorts, as is the case in languages whose syntax treats question words and other operator material alike in placing these into lower left-peripheral positions. Modifying the syntactic feature content of the [E]-feature to the feature(s) checked by whitems in a given language enabled us to neatly account for the Hungarian facts without any further assumptions. The new taxonomy of sluicing constructions we proposed by this modification provides a simple tool for predicting crosslinguistic variation in sluicing constructions as well, with respect to both the type and the structural position occupied by the remnants. These results also have welcome consequences for the analysis of sluicing-type phenomena in English. We showed that the modified [E]-feature opens a new possibility in accounting for hitherto problematic embedded/root asymmetries in the availability of stripping and fragment answers in English.

\section{References}

BARTOS, H. 2000. VP ellipsis and verbal inflection in Hungarian. Acta Linguistica Hungarica 47:3-23.

BRODY, M. 1990. Some remarks on the focus field in Hungarian. UCL Working Papers in Linguistics 2:201-225.

BRODY, M. 1995. Focus and checking theory. In Approaches to Hungarian 5, ed. I. Kenesei, 29-44. Szeged: JATE Press.

CHOMSKY, N. 1995. The Minimalist Program. Cambridge, MA: MIT Press.

CINQUE, G. 1999. Adverbs and functional heads: A cross-linguistic perspective. Oxford: Oxford University Press.

CRAENENBROECK, J. VAN 2004. Ellipsis in Dutch dialects. Ph.D. dissertation, Leiden University.

CRAENENBROECK, J. VAN \& A. LIPTÁK. 2005. Ellipsis in Hungarian and the typology of sluicing. In Ellipsis in Minimalism, ed. K. Choi \& C. Yim, 103-133. Seoul: Hankook.

CRAENENBROECK, J. VAN \& A. LIPTÁK. 2006. Verb movement bled by ellipsis: Morphological evidence from Hungarian. Talk presented at the TIN-dag, February 4, 2006, Utrecht University.

DIKKEN, M. DEN 2003. On the morphosyntax of wh-movement. In Multiple whfronting, ed. C. Boeckx \& K. Grohmann, 77-98. Amsterdam: John Benjamins.

DIKKEN, M. DEN \& A. GIANNAKIDOU. 2002. From hell to polarity: "Aggressively non-D-linked wh-phrases" as polarity items. Linguistic Inquiry 33:31-61.

É. KISS, K. 1987. Configurationality in Hungarian. Budapest: Akadémiai Kiadó.

É. KISS, K. 1992. Move-alpha and scrambling in Hungarian. In Approaches to Hungarian 4, ed. I. Kenesei \& C. Pléh, 67-98. Szeged: JATE Press.

É. KISS, K. 2001. Parasitic gaps revisited. In Parasitic gaps, ed. P. Culicover \& P. Postal, 99-124. Cambridge, MA: MIT Press.

FUJII, T. \& H. ONO. 2005. English $w h$-exclamatives and T-to-C-movement. Ms., University of Maryland, College Park.

FUKAYA, T. \& H. HOJI. 1999. Stripping and sluicing in Japanese and some implications. In Proceedings of WCCFL 18, ed. S. Bird, A. Carnie, J. D. Haugen \& P. Norquest, 145-158. Somerville, MA: Cascadilla Press. 
GREBANYOVA, L. 2006. Sluicing puzzles in Russian. Proceedings of the annual workshop on Formal Approaches to Slavic Linguistics 14:156-170.

HARDT, D. 1993. Verb phrase ellipsis: Form, meaning, and processing. Ph.D. dissertation, University of Pennsylvania, Philadelphia.

HOYT, F. \& A. THEODORESCU. To appear. How many kinds of sluicing, and why? Single and multiple sluicing in Romanian, English, and Japanese. In Sluicing: Crosslinguistic perspectives, ed. J. Merchant. Amsterdam: John Benjamins.

KENESEI, I. 1986. On the logic of word order in Hungarian. In Topic, focus, and configurationality, ed. W. Abraham \& S. de Meij, 143-159. Amsterdam: John Benjamins.

KENESEI, I. 1994. Subordinate clauses. In The syntactic structure of Hungarian: Syntax and semantics 27, ed. F. Kiefer \& K. É. Kiss, 275-354. San Diego, CA: Academic Press.

LOBECK, A. 1995. Ellipsis: Functional heads, licensing, and identification. Oxford: Oxford University Press.

MERCHANT, J. 2001. The syntax of silence. Oxford: Oxford University Press.

MERCHANT, J. 2003. Remarks on stripping. Ms., University of Chicago.

MERCHANT, J. 2004. Fragments and ellipsis. Linguistics and Philosophy 27:661-738.

MERCHANT, J. To appear. Variable island repair under ellipsis. In Topics in ellipsis, ed. K. Johnson. Cambridge: Cambridge University Press.

MOLTMANN, F. \& A. SZABOLCSI. 1994. Scope interactions with pair-list quantifiers. In Proceedings of NELS 24, ed. M. Gonzàlez, 381-395. Amherst, MA: GLSA Publications.

PARTEE, B. 1995. Quantificational structures and compositionality. In Quantification in natural languages, ed. E. Bach, E. Jelinek, A. Kratzer \& B. H. Partee, 541-601. Dordrecht: Kluwer.

ROSS, J. R. 1969. Guess who? In Papers from the fifth regional meeting of the Chicago Linguistic Society, ed. R. Binnick, A. Davidson, G. Green \& J. Morgan, 252-286. Chicago: Chicago Linguistic Society.

RUDIN, C. 1988. On multiple questions and multiple wh-fronting. Natural Language \& Linguistic Theory 6:445-501.

SZABOLCSI, A. 1997. Strategies for scope taking. In Ways of scope taking, ed. A. Szabolcsi, 109-154. Dordrecht: Kluwer.

SZCZEGELNIAK, A. 2004. Relativization and ellipsis. Ph.D. dissertation, Harvard University, Cambridge, MA.

WYNGAERD VANDEN, G. \& C. J.-W. ZWART. 1991. Reconstruction and vehicle change. In Linguistics in the Netherlands 1991, ed. F. Drijkoningen \& A. van Kemenade 151-160. Amsterdam: John Benjamins.

Anikó Lipták

LUCL, Leiden University

2300 RA Leiden

P.O. Box 9515

The Netherlands

a.liptak@let.leidenuniv.nl
Jeroen van Craenenbroeck Catholic University of Brussels Facultés universitaires Saint-Louis Vrijheidslaan 17 1081 Brussels Belgium

jeroen.vancraenenbroeck@kubrussel.ac.be 